\title{
Identification and analysis of the germin-like gene family in soybean
}

Mo Lu', Ying-Peng Han', Ji-Guo Gao ${ }^{2}$, Xiang-Jing Wang ${ }^{2 *}$, Wen-Bin Li ${ }^{1^{*}}$

\begin{abstract}
Background: Germin and germin-like proteins constitute a ubiquitous family of plant proteins. A role of some family members in defense against pathogen attack had been proposed based on gene regulation studies and transgenic approaches. Soybean (G. max L. Merr.) germin genes had not been characterized at the molecular and functional levels.

Results: In the present study, twenty-one germin gene members in soybean cultivar 'Maple Arrow' (partial resistance to Sclerotinia stem rot of soybean) were identified by in silico identification and RACE method (GmGER 1 to GmGER 21). A genome-wide analyses of these germin-like protein genes using a bioinformatics approach showed that the genes located on chromosomes 8, 1, 15, 20, 16, 19, 7, 3 and 10, on which more disease-resistant genes were located on. Sequence comparison revealed that the genes encoded three germin-like domains. The phylogenetic relationships and functional diversity of the germin gene family of soybean were analyzed among diverse genera. The expression of the GmGER genes treated with exogenous IAA suggested that GmGER genes might be regulated by auxin. Transgenic tobacco that expressed the GmGER 9 gene exhibited high tolerance to the salt stress. In addition, the GmGER mRNA increased transiently at darkness and peaked at a time that corresponded approximately to the critical night length. The mRNA did not accumulate significantly under the constant light condition, and did not change greatly under the SD and LD treatments.

Conclusions: This study provides a complex overview of the GmGER genes in soybean. Phylogenetic analysis suggested that the germin and germin-like genes of the plant species that had been founded might be evolved by independent gene duplication events. The experiment indicated that germin genes exhibited diverse expression patterns during soybean development. The different time courses of the mRNAs accumulation of GmGER genes in soybean leaves appeared to have a regular photoperiodic reaction in darkness. Also the GmGER genes were proved to response to abiotic stress (such as auxin and salt), suggesting that these paralogous genes were likely involved in complex biological processes in soybean.
\end{abstract}

\section{Background}

Germin is a protein marker that was first discovered in the germination of wheat seeds [1]. Subsequently, germin and germin-like proteins (GLPs) were found in other monocotyledonous, several dicotyledonous, angiosperms, gymnospermous plants, a myxomycete (slime mould) and Physarum polycephalum [2-10].

\footnotetext{
* Correspondence: wangxiangjing2008@yahoo.com.cn; wenbinli@neau. edu.cn

'Soybean Research Institute (Key Laboratory of Soybean Biology in Chinese Ministry of Education), Northeast Agricultural University, Harbin, PR China 150030

2Department of Life Science, Northeast Agricultural University, Harbin, PR China 150030

Full list of author information is available at the end of the article
}

Germin relatives have also been identified in fern spores, prokaryotes and animals [11,12].

The germin family comprises a group of proteins belonging to a superfamily. All germins contain the germin motif that gives rise to a predicted $\beta$-barrel core involved in metal binding [13]. Most of them share biochemical attributes such as seed storage proteins, globulins and sucrose-binding, though they differ in their tissue specificities and enzyme activities [14-18]. The germin genes seemed to be involved in various important processes including development, osmotic regulation, photoperiodic oscillation, defence and apoptosis [19], and also founded to be associated with cell wall deposition $[5,7,20,21]$.

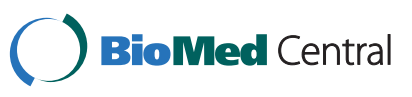


Germin has an oxalate oxidase (EC 1.2.3.4) activity [1]. There has been growing evidence that germin encoded an enzyme that degraded oxalate to $\mathrm{CO}_{2}$ and $\mathrm{H}_{2} \mathrm{O}_{2}$ and also releases $\mathrm{Ca}^{++}$in some plant species. The degraded residual $\mathrm{H}_{2} \mathrm{O}_{2}$ plays different roles: a molecular signal for the induction of defence mechanisms, cross-linking of polymers in the extracellular matrix synthesis [9], and a direct antimicrobial effect, such as lignifications, to reinforce the cell walls [22-24]. The germin protein in monocotyledonous appeared to have an oxalate oxidase activity [21], but the germin-like proteins in dicotyledonous plants did not appear to have oxalate oxidase activity by 2010 [19]. For example, wheat and barley germin genes were found in the apoplast and the cytoplasm of germinating embryo cells with oxalate oxidase activity [21]. Two genes (gf-2.8 and gf-3.8) and a transcript (cDNA) of wheat germin have been sequenced [1].

Some germin genes may have functions other than oxalate oxidase activity [25]. Germin-like gene mRNAs have been found in leaves, cotyledons, stems, roots, embryos, flowers, seeds, and some were produced in response to environmental stimuli, depending on the species or the genes under consideration. Several evidences suggested that some GLPs have functions in general plant defence responses [26]. For instance, infection with pathogens, feeding of insects or application of chemicals such as salicylic acid, hydrogen peroxide $\left(\mathrm{H}_{2} \mathrm{O}_{2}\right)$ or ethylene [27-32] could increase the expression of GLPs. In wheat and barley, transcription of at least one germin gene was induced upon a fungal infection [33]. Endogenous factors also controlled the expression of some germin genes since transcription of wheat germin gf-2.8 gene is stimulated by auxins [20]. Transient overexpression and transient silencing of certain barley GLP genes resulted in enhanced resistance to the powdery mildew fungus [17]. The promoter variant of rice oxalate oxidase genes played a role in resistance to Magnaporthe oryzae [34]. For some subfamilies, transient and stable expression showed a superoxide dismutase activity (EC1.15.1.1) of the encoded protein [31]. Silencing of a Nicotiana attenuata GLP increased the performance of an herbivore [30]. mRNA levels of mustard (Brassica napus) and a closely related Arabidopsis germin gene fluctuated during the circadian cycle $[5,8]$.

Sclerotinia stem rot (SSR) caused by Sclerotinia sclerotiorum (Lib.) De Bary is a serious fungal disease of soybean. Since oxalic acid is a major pathogenic factor of SSR, transgenic soybean capable of degrading oxalic acid may be resistant to the pathogen [35]. To date, the wheat gf- 2.8 gene has been studied on resistance to the oxalate-secreting pathogen S. sclerotiorum. Results showed transgenic soybean with the wheat germin gene greatly reduced disease progression and lesion length following cotyledon and stem inoculation with S. sclerotiorum, indicating that the germin gene products conferred resistant to Sclerotinia stem rot [35].

The GLPs with mostly unknown function in plant genomes [26] had been classified into subfamilies $[36,37]$. For example, the true germin subfamily, such as wheat and barley germins, included proteins with oxalate oxidase activity. In contrast, both GLP subfamilies 1 and 2 contained examples of proteins with superoxide dismutase (SOD) activity. Subfamily 3 included the phosphodiesterase (EC3.1) activity described above, and more subdivisions had been proposed recently [38]. A key feature of the GLP-related subfamilies, including the germins [37], was the conservation of a motif derived from that of the cupin superfamily [36]. In barley, five GLP subfamilies have been described and named HvGER1 to HvGER5. In Physcomitrella patens germinlike proteins, two novel clades have been found, named bryophyte-subfamilies 1 and 2 [38].

In contrast to the advanced knowledge of the structure, cell biology and expression features of barley and wheat germins and GLPs, less was known about soybean germin and germin-like genes by 2010 . In the present work, nearly 50,000 sequenced and annotated ESTs of soybean were analyzed to find GmGER-like sequences by amino acid sequence similarity, and GmGER-like sequences were elongated by RACE. Their locations were determined and compared to disease resistance QTL, and both cluster and phylogenetic analyses of the germin-like proteins were performed to describe the variations in the soybean gene family. The abiotic factors (auxin-IAA, salt, light treatments) was tested on GmGER genes to evaluate the complex biological processes related to soybean development.

\section{Results}

Mining of germin-like EST sequences from soybean database and the determination of full-length CDNA sequences of GmGER genes

123 soybean germin and germin-like EST sequences were detected by BLASTP and TBLASTN searches against the GenBank database. In addition, 204 nucleic acid sequences (both of the genes and ESTs) of germin and germin-like genes from 30 other plant species in the databases were collected for comparison to soybean data [Figure 1, Table 1 and 2]. After subsequent survey of soybean genomic data, twenty-one soybean germinlike ESTs or full length of cDNA genes were obtained. Of them two full-length mRNA was isolated by RACE. These genes were named as GmGER 1 to GmGER 21 and registered in NCBI GenBank [Table 2]. The open reading frames (ORFs) of the germin-like protein encoding genes were complementary DNA, and each gene had one exon. Most of the genes were transcribed from a 


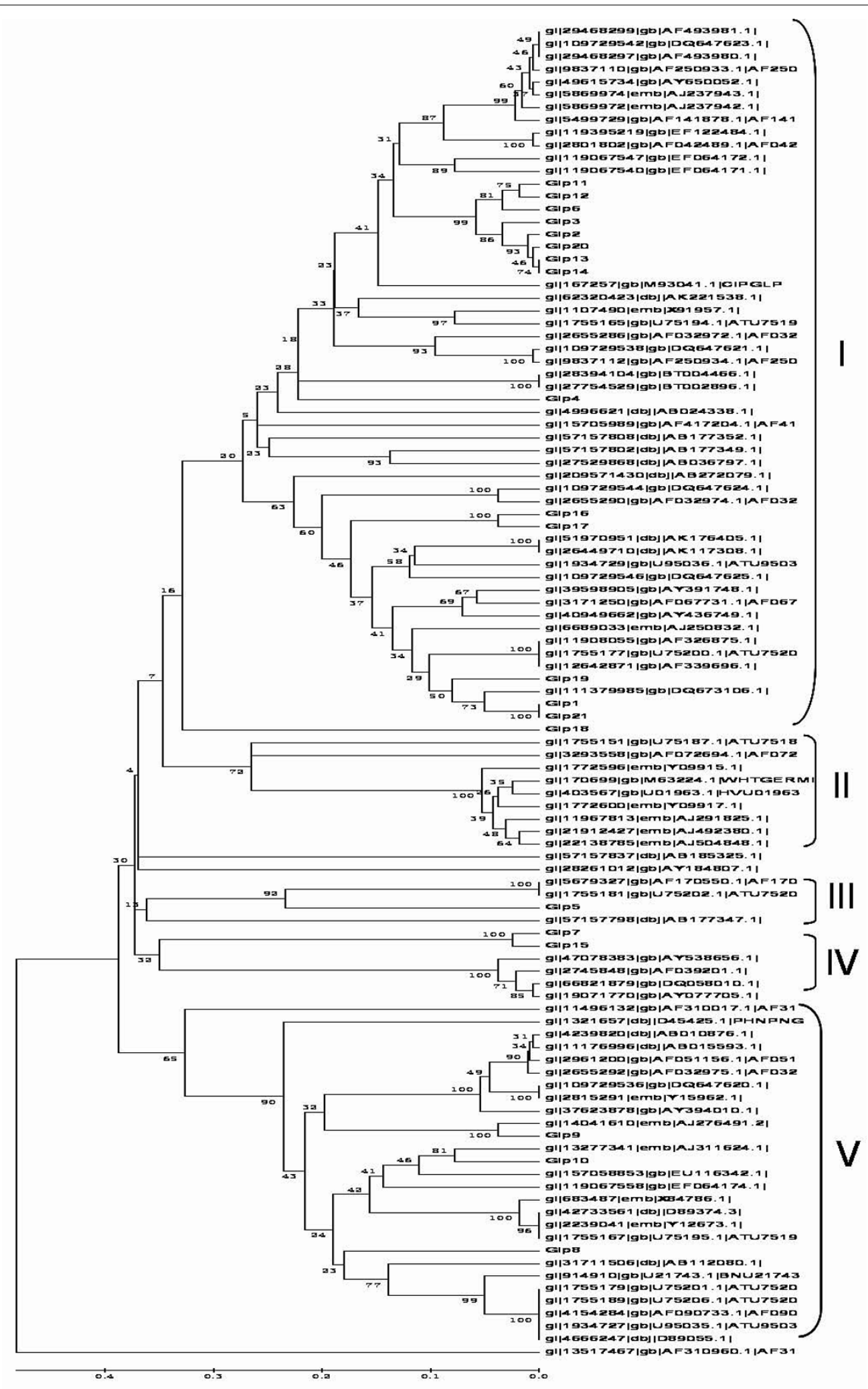

Figure 1 Unrooted phylogenetic tree was constructed using the coding sequences of the GmGER genes and those of different plant species. Bootstrap values were placed at the nodes and the scale bar corresponded to 0.1 estimated nucleic acid substitutions per site. Five major classes (I to V) were shown. 
Table 1 Accession numbers of germin family gene and protein sequences used in phylogenetic analyses

\begin{tabular}{|c|c|c|c|c|c|}
\hline Gene Name & Accession No. ${ }^{a}$ & Plant species & Gene Name & Accession No. ${ }^{a}$ & Plant species \\
\hline OsGLP1 & $\begin{array}{l}\text { AB010876 } \\
\text { AB015593 }\end{array}$ & Oryza sativa & GER1 & EF064171 & Vitis vinifera \\
\hline KCS334B01 & EF122484 & Oryza sativa & GER2 & DQ673106 & Vitis vinifera \\
\hline GER1 & AF032971 & Oryza sativa & GER3 & AY298727 & Vitis vinifera \\
\hline GER2 & AF032972 & Oryza sativa & GER4 & EF064172 & Vitis vinifera \\
\hline GER4 & AF032974 & Oryza sativa & GER5 & EF064173 & Vitis vinifera \\
\hline GER5 & AF032975 & Oryza sativa & GER6 & EF064174 & Vitis vinifera \\
\hline GER6 & AF032976 & Oryza sativa & GER7 & EF064175 & Vitis vinifera \\
\hline GER7 & AF072694 & Oryza sativa & GLP & EU116342 & $\begin{array}{l}\text { Chimonanthus } \\
\text { praecox }\end{array}$ \\
\hline RGLP1 & $\begin{array}{l}\text { AF141880 } \\
\text { AF141878 }\end{array}$ & Oryza sativa & PnGLP & D45425 & Ipomoea nil \\
\hline RGLP2 & AF141879 & Oryza sativa & glp1 & AY394010 & Zea \\
\hline GLP2a & U75192 & Oryza sativa & GLP4 & AY650052 & $\begin{array}{l}\text { Triticum } \\
\text { monococcum }\end{array}$ \\
\hline GLP3b & U75193 U75195 & Oryza sativa & GLP & M21962 & Triticum aestivum \\
\hline GLP3b & U75193 U75195 & Oryza sativa & Glp3 & Y09917 & Triticum aestivum \\
\hline GLP16 & AF042489 & Oryza sativa & Glp1 & Y09915 & Triticum aestivum \\
\hline GLP110 & AF051156 & Oryza sativa & Glp2b & AJ237943 & Triticum aestivum \\
\hline ger1 & AJ250832 & Pisum sativum & Glp2a & AJ237942 & Triticum aestivum \\
\hline glp3 & AJ311624 & Pisum sativum & GerA & AF250933 & Hordeum vulgare \\
\hline $9 f-3.8$ & M63224 & Wheat & GerB & AF250934 & Hordeum vulgare \\
\hline $9 f-2.8$ & M63223 & Wheat & GerD & AF250936 & Hordeum vulgare \\
\hline RmGLP1 & AB272079 & Rhododendron mucronatum & GerF & AF250935 & Hordeum vulgare \\
\hline RmGLP2 & AB272080 & Rhododendron mucronatum & GLP1 & Y15962 & Hordeum vulgare \\
\hline Ger & AY436749 & Nicotiana attenuata & GL8 & AF493980 & Hordeum vulgare \\
\hline glp & AB112080 & Nicotiana tabacum & GL12 & AF493981 & Hordeum vulgare \\
\hline $\mathrm{oxO1}$ & AJ291825 & Lolium perenne & GER1a & DQ647619 & Hordeum vulgare \\
\hline $\mathrm{oxO} 2$ & AJ492380 & Lolium perenne & GER2a & DQ647620 & Hordeum vulgare \\
\hline $0 \times 03$ & AJ504848 & Lolium perenne & GER3a & DQ647621 & Hordeum vulgare \\
\hline $\mathrm{oxO} 4$ & AJ492381 & Lolium perenne & GER4C & DQ647622 & Hordeum vulgare \\
\hline Glp1 & $\mathrm{X} 84786$ & Sinapis alba & GER4d & DQ647623 & Hordeum vulgare \\
\hline Glp & AY391748 & Capsicum annuum & GER5a & DQ647624 & Hordeum vulgare \\
\hline Glp1 & AY184807 & Medicago truncatula & GER6a & DQ647625 & Hordeum vulgare \\
\hline OXAOXA & AF067731 & Solanum tuberosum & HVGLP1 & Y15962 & Hordeum vulgare \\
\hline BuGLP & AB036797 & Barbula unguiculata & CM 72 & U01963 & Hordeum vulgare \\
\hline Ger171 & AF310017 & Musa acuminata & GER1 & DQ058010 & Larix $x$ marschlinsii \\
\hline$\overline{G L P}$ & AB024338 & Atriplex lentiformis & glp1 & AJ276491 & Phaseolus vulgaris \\
\hline CIPGLP & M93041 & $\begin{array}{l}\text { Mesembryanthemum } \\
\text { crystallinum }\end{array}$ & BNU21743 & U21743 & Brassica napus \\
\hline Ger171 & AF310017 & Beta vulgaris oxalate & PCGER1 & AF039201 & Pinus caribaea \\
\hline Ger165 & AF310016 & Beta vulgaris oxalate & GER1 & AY077705 & Pinus sylvestris \\
\hline p2-A & AF310960 & Linum usitatissimum & GER1 & AY077704 & Pinus caribaea \\
\hline PpGLP1a PpGLP1b & $\begin{array}{l}\text { AB177646 } \\
\text { AB177347 }\end{array}$ & Physcomitrella patens subsp & GLP1 & AY538656 & Pinus taeda \\
\hline PpGLP2 & $\begin{array}{l}\text { AB185322 } \\
\text { AB177348 }\end{array}$ & Physcomitrella patens subsp & At1g09560 & AF339696 AF326875 & Arabidopsis thaliana \\
\hline PpGLP3a & AB177349 & Physcomitrella patens subsp & At3g04200 & BT004466 BT002896 & Arabidopsis thaliana \\
\hline PpGLP3b & AB177645 & Physcomitrella patens subsp & RAFL07 & AK221538 & Arabidopsis thaliana \\
\hline
\end{tabular}


Table 1 Accession numbers of germin family gene and protein sequences used in phylogenetic analyses (Continued)

\begin{tabular}{|c|c|c|c|c|c|}
\hline PpGLP4 & $\begin{array}{l}\text { AB185323 } \\
\text { AB177350 }\end{array}$ & Physcomitrella patens subsp & RAFL24 & AK176405 & Arabidopsis thaliana \\
\hline PpGLP5 & $\begin{array}{l}\text { AB185324 } \\
\text { AB177351 }\end{array}$ & Physcomitrella patens subsp & AtGER2 & X91957 & Arabidopsis thaliana \\
\hline PpGLP6 & $\begin{array}{l}\text { AB185492 } \\
\text { AB177352 }\end{array}$ & Physcomitrella patens subsp & AtGLP1 & D89055 & Arabidopsis thaliana \\
\hline PpGLP7 & $\begin{array}{l}\text { AB177353 } \\
\text { AB185325 }\end{array}$ & Physcomitrella patens subsp & AtGLP2 & D89374 & Arabidopsis thaliana \\
\hline GLP1 & $\begin{array}{l}\text { NM_105920 F090733 U75190 } \\
\text { U75189 U75196 U75197 } \\
\text { U75201 U75206 U95034 } \\
\text { U95035 }\end{array}$ & Arabidopsis thaliana & GL22 & NM_001083981 & Arabidopsis thaliana \\
\hline GLP3 & NM_122070 Y12673 & Arabidopsis thaliana & AT3G05950 & NM_111469 & Arabidopsis thaliana \\
\hline GLP4 & NM_101754 U75187 & Arabidopsis thaliana & AT5G26700 & NM_180544 & Arabidopsis thaliana \\
\hline GLP5 & $\begin{array}{l}\text { NM_100827 U75191 U75198 } \\
\text { U75200 }\end{array}$ & Arabidopsis thaliana & AT5G38910 & NM_123253 & Arabidopsis thaliana \\
\hline GLP6 & NM_123272 & Arabidopsis thaliana & AT5G38930 & NM_123255 & Arabidopsis thaliana \\
\hline GLP7 & NM_100920 AF170550 & Arabidopsis thaliana & AT5G38940 & NM_123256 & Arabidopsis thaliana \\
\hline GLP8 & NM_111467 & Arabidopsis thaliana & AT5G38950 & NM_123257 & Arabidopsis thaliana \\
\hline GLP9 & NM_117545 & Arabidopsis thaliana & AT5G38960 & NM_123258 & Arabidopsis thaliana \\
\hline GLP10 & $\begin{array}{l}\text { NM_116067 } \\
\text { NM_202748 }\end{array}$ & Arabidopsis thaliana & AT5G39110 & NM_123273 & Arabidopsis thaliana \\
\hline GLP2a & $\begin{array}{l}\text { NM_001125862 } \\
\text { NM_123281 U75192 }\end{array}$ & Arabidopsis thaliana & AT5G39120 & NM_123274 & Arabidopsis thaliana \\
\hline GLP3a & U75188 U75203 & Arabidopsis thaliana & AT5G39130 & NM_123275 & Arabidopsis thaliana \\
\hline GLP3b & U75193 U75195 & Arabidopsis thaliana & AT5G39150 & NM_123277 & Arabidopsis thaliana \\
\hline AT1G18980 & NM_101755 & Arabidopsis thaliana & AT5G39160 & NM_001036906 & Arabidopsis thaliana \\
\hline AT3G10080 & NM_111843 & Arabidopsis thaliana & AT5G39180 & NM_123280 & Arabidopsis thaliana \\
\hline AT3G04150 & NM_111286 & Arabidopsis thaliana & ATU75194 & U75194 & Arabidopsis thaliana \\
\hline AT3G04170 & NM_111288 & Arabidopsis thaliana & ATU75202 & U75202 & Arabidopsis thaliana \\
\hline AT3G04180 & NM_111289 & Arabidopsis thaliana & ATU75207 & U75207 & Arabidopsis thaliana \\
\hline AT3G04190 & NM_111290 & Arabidopsis thaliana & ATU95036 & U95036 & Arabidopsis thaliana \\
\hline AT3G04200 & NM_111291 & Arabidopsis thaliana & At1g02335 & AK117308 & Arabidopsis thaliana \\
\hline
\end{tabular}

a Gene sequences were acquired from the NCBI sequence database http://www.ncbi.nlm.nih.gov/. Germin sequences from crop plants with published gene and/ or protein expression data were included in the analysis.

single exon. The analyses of germin-like gene domain revealed that all of the GmGER genes had the similar domains that were lineated up closely each other [Figure 2] except the different position. The structure contained three boxes that represented the germin domains. The overall analyses revealed that the 21 proteins that contained the germin domains formed a single germin-like family in soybean.

\section{Chromosomal locations of GmGER genes}

Twenty-one genes of the soybean germin-like proteins were distributed on chromosomes $(\mathrm{CH}) 8,1,15,20,16$, 19, 7, 3 and 10, respectively. An example of integration of the genetic and physical map with genetic markers for a detailed region of $\sim 8 \mathrm{cM}$ length on linkage group (LG) is illustrated in Figure 3. Among them, GmGER 7 was located at $106.7 \mathrm{cM}$ on LG A2 (CH 8). GmGER 5 was located at $44.7 \mathrm{cM}$ on LG D1a (CH 1). GmGER 10 and GmGER 15 were located at 43.0 and $44.6 \mathrm{cM}$ on LG E (CH 15). GmGER 11, GmGER 12, GmGER 18 and GmGER 19 were located at 107.8, 103.2, 48.3 and 108.7 cM on LG I ( $\mathrm{CH} 20$ ), respectively. GmGER 2, GmGER 3 and GmGER 4 were located at 32.1, 30.1 and $30.4 \mathrm{cM}$ on LG J (CH 16). GmGER 14 and GmGER 20 were located at $30.9 \mathrm{cM}$ on LG L (CH 19). GmGER 6 and GmGER 9 were located at 23.6 and $30.3 \mathrm{cM}$ on LG M (CH 7). GmGER 1 and GmGER 21 were located at 104.5 and $105.3 \mathrm{cM}$ on LG N (CH 3). GmGER 6, GmGER 16 and GmGER 17 were located at 83.3, 50.3 and $53.5 \mathrm{cM}$ on LG O ( $\mathrm{CH} 10)$. There were several locations where single germin gene was dispersed and other genes appeared clustered. From the alignments between genetic markers and FPC contigs, few discrepancies of marker order between physical and genetic 
Table 2 List of the amino acid lengths of the 21 GmGER genes and their numbers in NCBI

\begin{tabular}{llll}
\hline Gene name & Accession number (Genebank) & Protein ID (Genebank) & Amino acid length \\
\hline GmGER 1 & EU916269 & ACL14493 & 1000 \\
GmGER 2 & EU916250 & ACG69478 & 666 \\
GmGER 3 & EU916251 & ACG69479 & 666 \\
GmGER 4 & EU916252 & ACG69480 & 648 \\
GmGER 5 & EU916253 & ACG69481 & 663 \\
GmGER 6 & EU916254 & ACG69482 & 699 \\
GmGER 7 & EU916255 & ACG69483 & 636 \\
GmGER 8 & EU916256 & ACG69484 & 630 \\
GmGER 9 & EU916257 & ACG69485 & 627 \\
GmGER 10 & EU916258 & ACG69486 & 642 \\
GmGER 11 & EU916259 & ACG69487 & 699 \\
GmGER 12 & EU916260 & ACG69488 & 669 \\
GmGER 13 & EU916261 & ACG69489 & 666 \\
GmGER 14 & EU916262 & ACG69490 & 666 \\
GmGER 15 & EU916263 & ACG69491 & 696 \\
GmGER 16 & EU916264 & ACG69492 & 666 \\
GmGER 17 & EU916265 & ACG69493 & 663 \\
GmGER 18 & EU916266 & ACG69494 & 696 \\
GmGER 19 & EU916267 & ACG69495 & 657 \\
GmGER 20 & EU916268 & ACG69496 & 666 \\
GmGER 21 & EU925816 & ACG69497 & 558
\end{tabular}

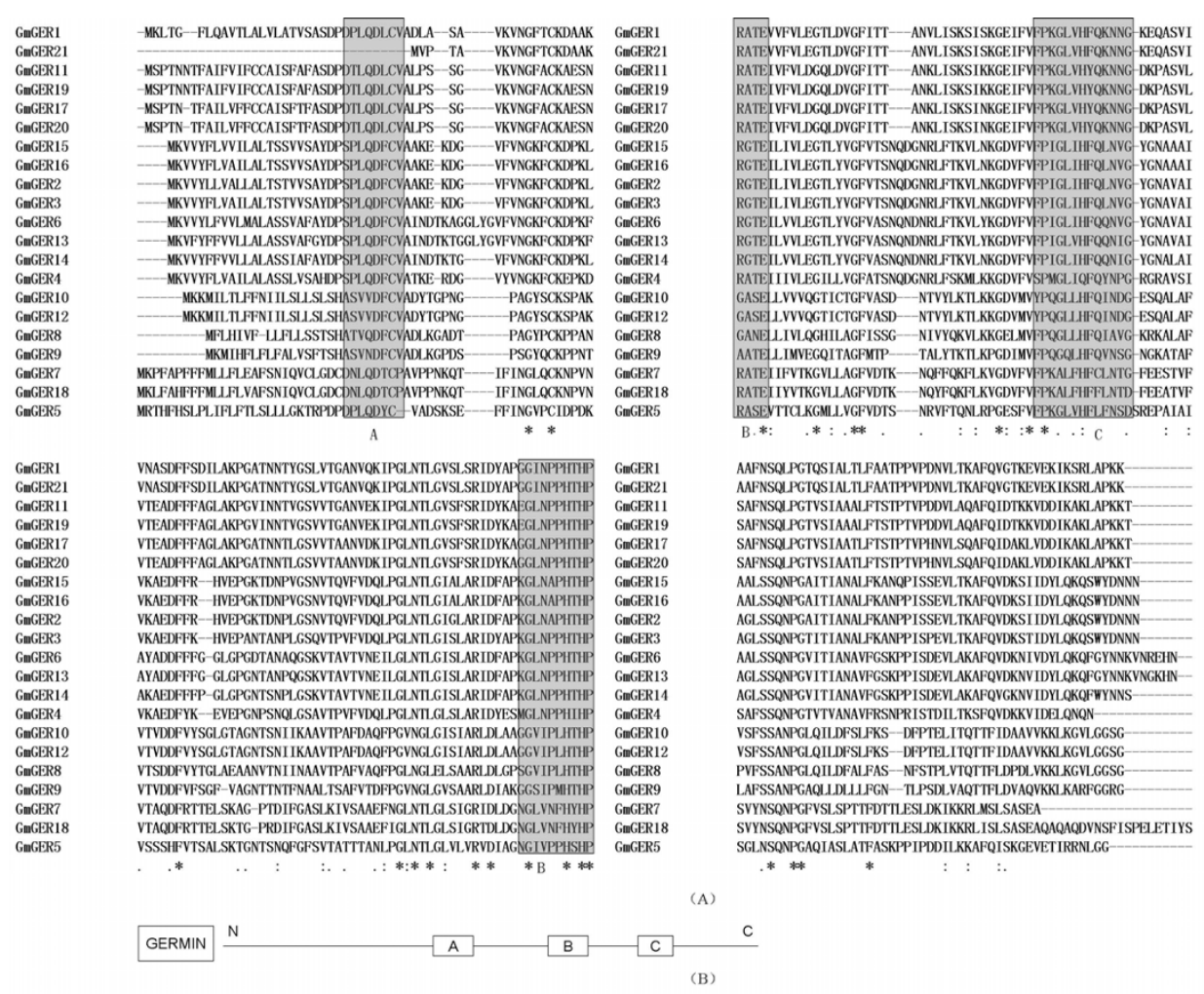

Figure 2 The alignment of the germin domain in soybean germin-like genes and schematic diagram of soybean GmGER genes. (A) The alignment of soybean germin-like protein domain was performed using the ClustalW program. (B) The rectangular boxes indicated the domains and their localization in each protein sequence. 
LG A2

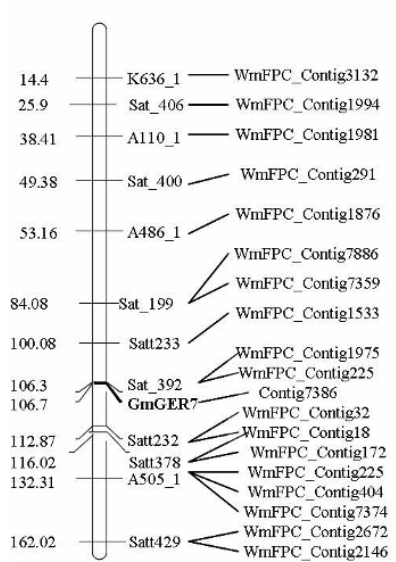

LG I
LG D1a

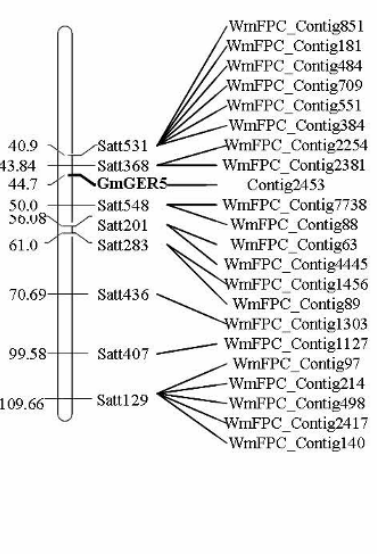

LG J
LGE

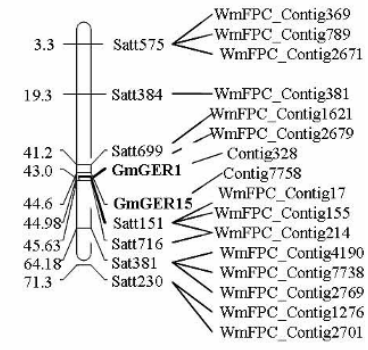

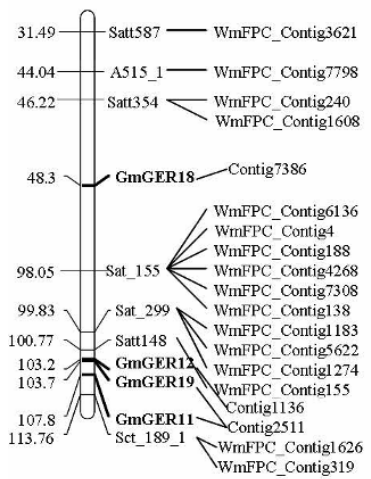

LG M

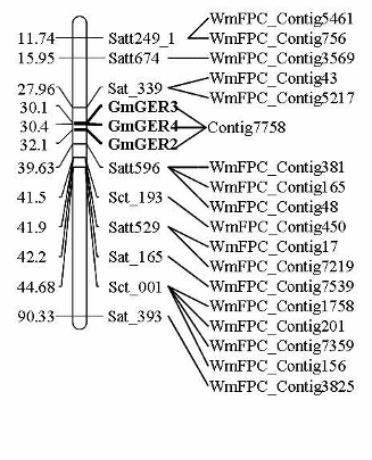

LG N

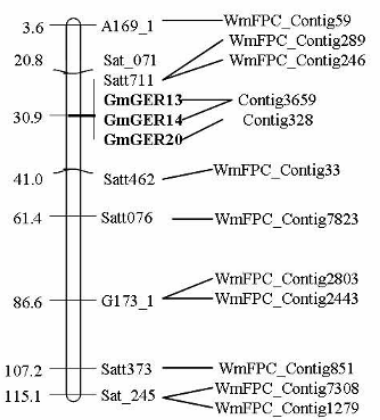

LG O
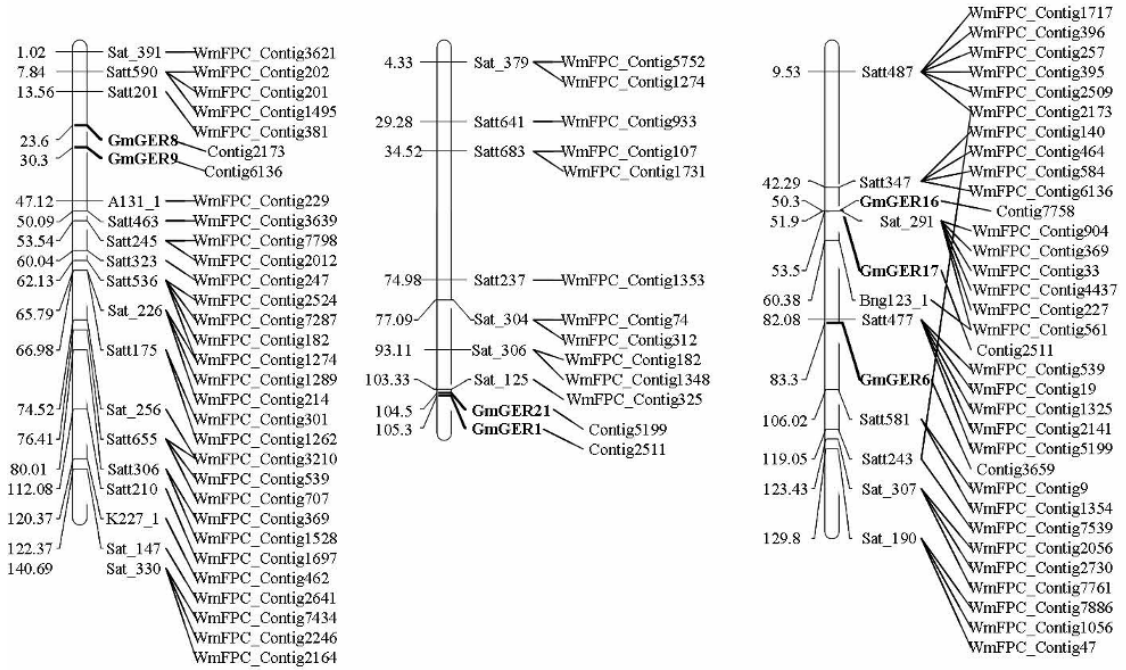

Figure 3 Genomic arrangement and orientation of soybean germin-like protein genes on linkage groups (chromosomes) A2 (8), D1a (1), E (15), I (20), J (16), L (19), M (7), N (3) and O (10). Arrows indicated the transcription orientation of the genes. The numbers represented the exact positions of each gene. The QTL name and position referred to the Soybean Breeders Toolbox. The lines indicated the discrepancies of marker alignments between the physical map and genetic map. 
maps were obvious. The 21 genes distributed to 17 FPC contigs. Some of the genes in each of the clusters were transcribed from the same strand, indicating that they might have arisen by direct duplication [Figure 3]. However, each gene in the cluster had miner difference in the nucleic acid structure, which might happen during soybean evolution.

\section{Multiple sequence alignment and phylogenetic tree for soybean germin gene family}

To uncover the common characteristics of proteins in germin-like gene families, the predicted protein sequences of the 21 soybean GmGER genes was compared [Figure 2]. All these proteins possessed one or two N-glycosylation consensus sequences. Three other conserved regions were found and might have important functions in these proteins. However, no precise function had been attributed to them to date. The three domains were located in the 3' end of the larger protein coding germin genes. The structure consensus sequence of motif A was HTHPRATEILTVLEGTLYVGF with 21 amino acids. The structure consensus sequence of motif B was KVLNKGDVFVFPEGLIHFQFN with 21 amino acids. The structure consensus sequence of motif $\mathrm{C}$ was [N/S]SQNPGIVFVPLTLFG with 16 amino acids.

A phylogenetic relationship of GmGER with the paralogous RNA helicases was inferred by constructing the neighbor-joining tree. The tree topology was found to be well aligned with the 21 evolutionary lineage among soybean derived from a broad array of clades. Also, the binary alignment analysis of the 21 GmGER genes with each predicted paralogous genes yielded consistent results supported by high sequence identity values. A RNA helicase protein, GmGER 2 and GmGER 20 exhibited the highest sequence identity with GmGER 13 and GmGER 14. GmGER 6 and GmGER 11 exhibited the highest sequence identity with GmGER 12 . GmGER 1 exhibited the highest sequence identity with GmGER 21 . GmGER 16 exhibited the highest sequence identity with GmGER 17. GmGER 8 exhibited the highest sequence identity with GmGER 9. GmGER 7 exhibited the highest sequence identity with GmGER 15 [Figure 4]. Phylogenetic analyses showed that all the GmGER genes were relatively tightly clustered together. Notably, these sequences were most closely related with those proteins sharing the same domains. The genes in the same group were closed to each other and far off the genes from the other groups. Therefore, the genes in the three groups might originate from different ancestors.

\section{Comparison of soybean germin family with other species by phylogenetic tree}

To study the phylogeny of the GmGER gene family, the complete germin protein sequences of different species

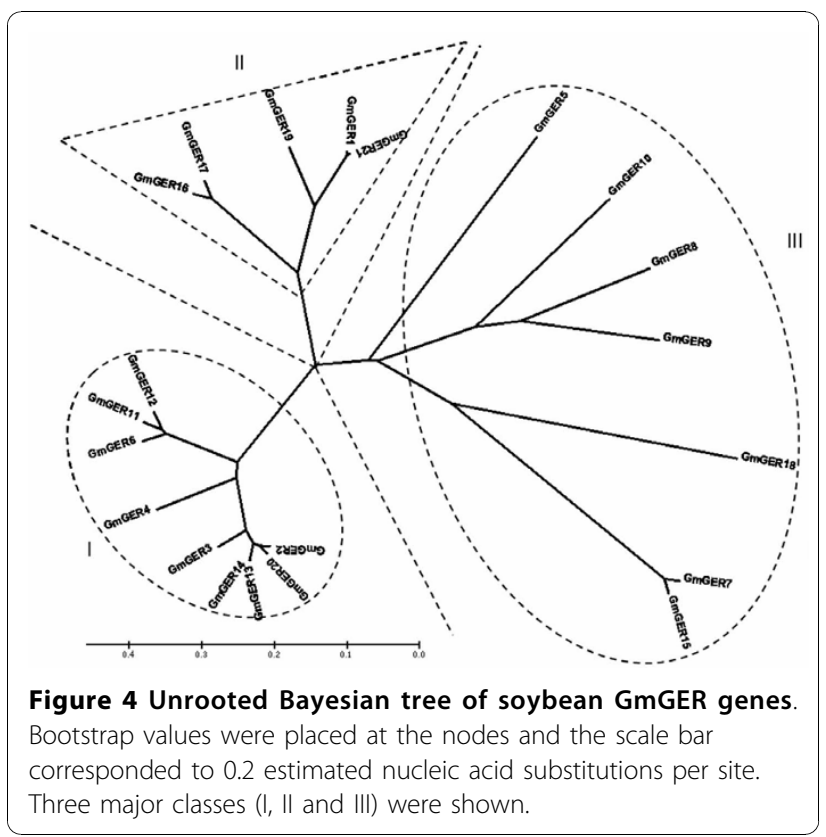

were collected. Redundant or highly similar sequences were removed and a phylogenetic tree with 105 complete GLP sequences was constructed with the neighbor-joining method [Figure 1]. The results showed a complex evolutionary history existed with recent gene duplications of soybean due to the difficulty to identify orthologs of particular soybean germins in other species. However, subfamilies of germin genes had been described. A few clades [5] representing different species emerged. The germin-like gene family proteins in soybean and in other species were apparently divided into different clades [Figure 1]. The relationship among gene lineages were roughly congruent with established phylogenetic relationship among taxa. For example, relationships among gene lineages in the clade I subfamily corresponded closely with phylogenetic relationships among Arabidopsis, rice, Pisum sativum, Vitis vinifera, Hordeum vulgare, Triticum aestivum, Atriplex lentiformis, Musa acuminate, Rhododendron mucronatum, barley and wheat. The results from phylogenetic tree suggested that the conservation of tissue specific expression pattern existed within a few subfamilies.

The GmGER genes fell into five major clades. Clade I contained the largest number of the GLP subfamilies, including 15 members of the 21 GmGER genes. GmGER 1 was closely related to Vitis vinifera and Pisum sativum. GmGER 2 was closely related to Hordeum vulgare. GmGER 3 was closely related to Hordeum vulgare. GmGER 4 was closely related to Atriplex lentiformis and Musa acuminate. GmGER 6, GmGER 11, GmGER 12, GmGER 13, GmGER 14 and GmGER 20 were closely related to Triticum aestivum. GmGER 
16 and GmGER 17 were closely related to Rhododendron mucronatum. GmGER 19 was closely related to Pisum sativum. GmGER 21 was closely related to Pisum sativum and Vitis vinifera.

Clade II did not contain any GmGER gene. Included in this clade were Arabiopsis GLP gene members, two rice GLP genes, four barley GLP genes, one wheat GLP gene and three Lolium perenne GLP genes. This suggested that clade II was conserved in grasses. Clade III contained four members, including GmGER 5 gene, two Arabiopsis GLP genes and one Physcomitrella patens subsp. patens GLP gene. Clade III was conserved in both dicot and monocot plants. Clade IV contained six members, GmGER 7, GmGER 15, three Pinus GLP genes and one Larix $x$ marschlinsii (hybrid larch) GLP gene. It seemed that GmGER 7 and GmGER 15 were closely related to Pinus GLP genes. GmGER 8, GmGER 9 and GmGER 10 were covered in clade V, in that GLPs were widely dispersed in different plant species. GmGER 9 and Phaseolus vulgaris GLP genes were homologously grouped. GmGER 10 and Pisum sativum GLP gene were closely related to Chimonanthus praecox GLP gene and Vitis vinifera GLP gene. The three GmGER genes were also closely related to Beta vulgaris GLP gene and Linum usitatissimum cv. GLP genes.

\section{mRNA expression of GmGER genes in response to auxin-} IAA

The expression of the GmGER genes was dramatically stimulated within $8 \mathrm{~h}$ after the addition of IAA, maintained for $12 \mathrm{~h}$, and then decreased gradually, according to the results of real-time RT-PCR [Figure 5], suggesting that GmGER genes might be regulated by auxin.

\section{mRNA expression of GmGER genes under light stress}

Changes in the expression level of GmGER mRNA in leaves, under darkness, long day (LD) and short day

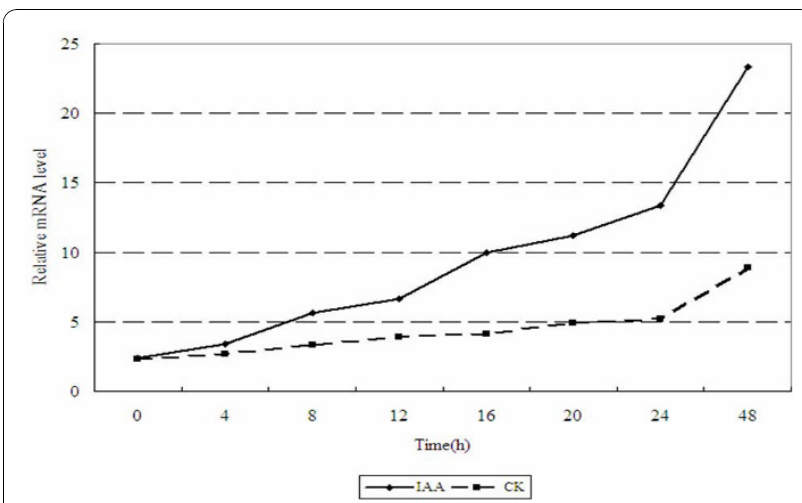

Figure 5 Expression analysis of the GmGER gene by quantitative real-time RT-PCR. The analyse is in response to IAA $(100 \mathrm{u}$ M) treatment at $0,4,8,12,16,20,24,48$ hours.
(SD) treatments, were examined by quantitative realtime RT-PCR. The level of GmGER mRNA showed an obvious increase and a decrease during $48 \mathrm{~h}$ of continuous darkness (peaked at $12 \mathrm{~h}$ and $36 \mathrm{~h}$ ), suggesting the existence of a circadian clock feature [Figure 6]. The expression of GmGER mRNA was not clear during the continuous light for $48 \mathrm{~h}$. The level of GmGER mRNA showed a moderate changes in SD and LD treatments (SD treatment being higher than LD treatment) [Figure 6].

\section{Salt tolerance of transgenic tobacco with GmGER 9 gene} Both fresh weight and stem length of transgenic tobacco plants were significantly higher than in the WT plants after exposure to 150, 250 and $350 \mathrm{mM}$ of $\mathrm{NaCl}$ [Figure $7 \mathrm{~B}, 7 \mathrm{C}, 7 \mathrm{D}, 7 \mathrm{E}$ and $7 \mathrm{~F}]$. Under the treatment of 350 $\mathrm{mM} \mathrm{NaCl}$, the WT plants grow smaller and yellower, whereas, the GmGER 9 transformed plants grow taller [Figure 7A, 7B, 7C and 7D]. There were no differences in fresh weight and stem length between WT and transgenic plants without $\mathrm{NaCl}$ supplement [Figure 7A, 7E and $7 F]$.

\section{Discussion}

Germin genes form a large family and their functions are still under studying. In this study, we identified 21 germin genes of soybean. The analyses of gene domain revealed that the unknown GLP gene family and their functions might be determined according to the presence of germin domain. Interestingly, the predicted model almost perfectly conformed to the determined structure of individual domain of the seed storage globulins, canavalin and phaseolin that showed a significant sequence similarity with germins $[39,40]$. These proteins contain two or three similar domains that might have evolved following gene duplication events from a common ancestral gene or domain $[40,41]$.

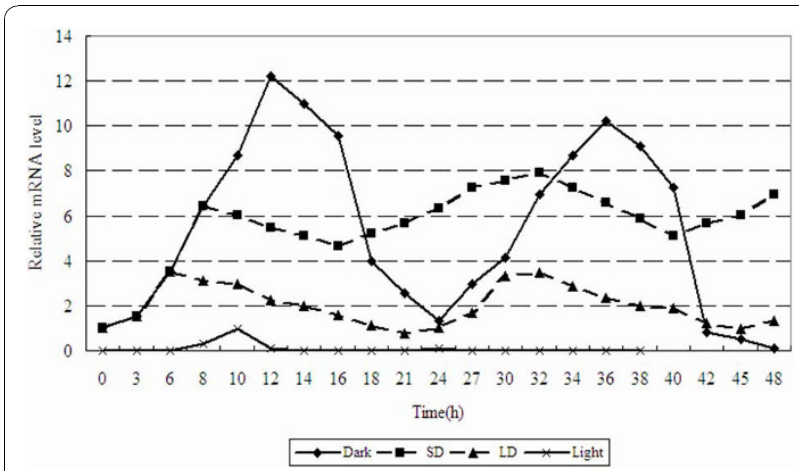

Figure 6 Expression level of GmGER mRNA in four photoperiodic treatments. Continuous darkness (up to $48 \mathrm{~h}$ ), continuous light (up to $48 \mathrm{~h}$ ), SD (short-day, $8 \mathrm{~h}$ light and $16 \mathrm{~h}$ dark), LD (long-day, $16 \mathrm{~h}$ light and $8 \mathrm{~h}$ dark). 


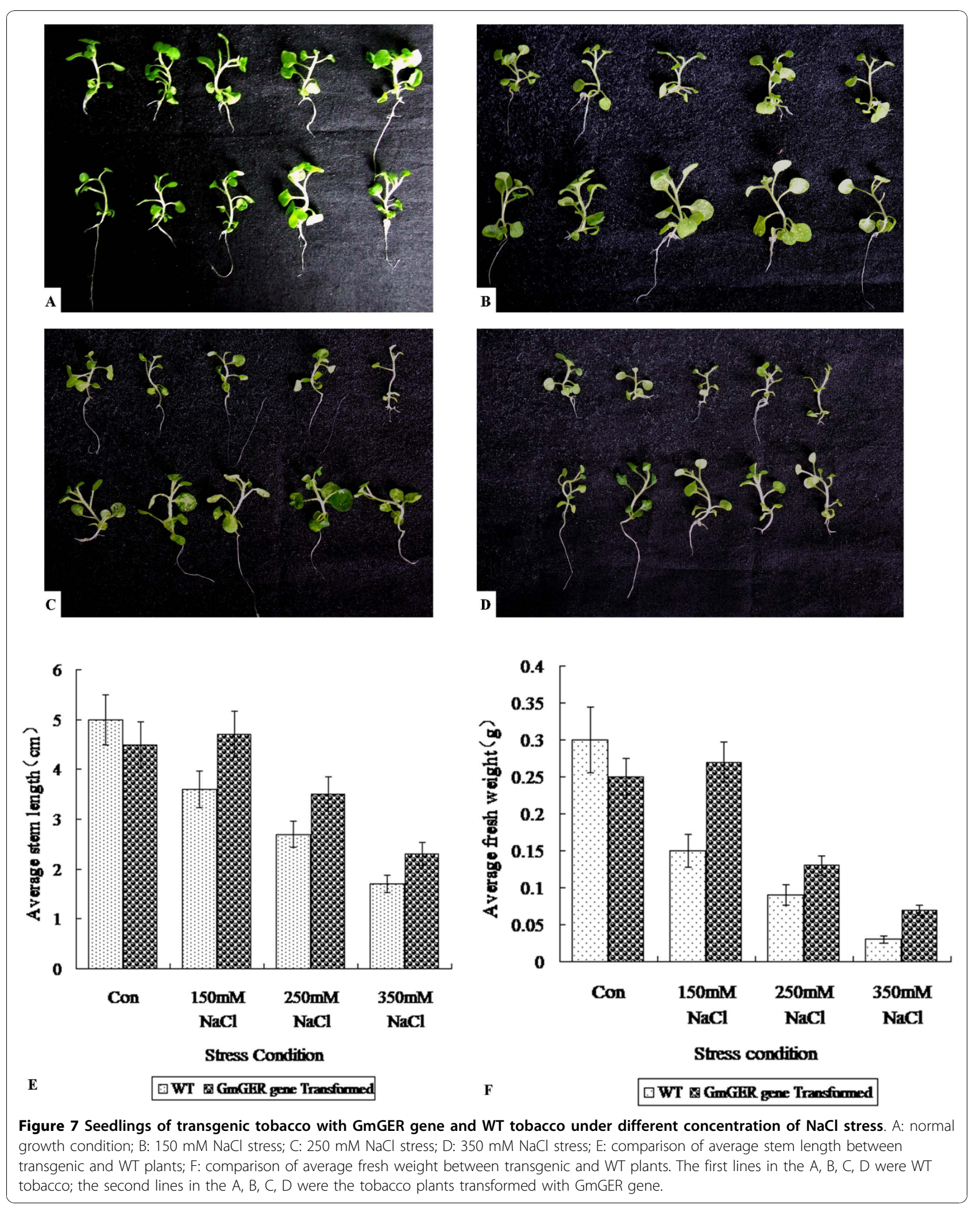


To date, no germin gene was identified in soybean. Thus, the 21 GmGER genes found in the present work were thought as the novel, species-specific proteins of soybean. Comparative analyses revealed that these evolutionary related germin genes shared very similar exon structures, suggested the close phylogenetic relationships among the soybean germin genes.

The common structural features of germin-like proteins included: conserved structural elements, secretory transit peptides, protein glycosylation sites and regions of conserved sequence similarity [36]. According to the review of Carter and Thornburg [36], the most important conserved structural feature among the GLPs is a conserved amino acid sequence termed the germin box. The consensus pattern is: GxxxxHAPxAxEh, where $\mathrm{x}$ is any amino acid and $h$ is a hydrophobic amino acid. Mature germins and GLPs all contain approximately 200 amino acids in length and the germin box occurs near the middle for all proteins in this family. In soybean, the conserved region $B$ was found in all the 21 germin genes. Conserved region A enriched in hydrophobic amino acids always followed this peptide (GxxxHeHPxAxEh) [Figure 2]. Another conserved region A was localized in the amino terminal part of the mature proteins, and strongly conserved in all the germins but not in the spherulins. It is likely that the heptapeptide sequence [L/V]QDFCV[A/G], found in all germin-like proteins examined, was of importance in the biochemical functions of these proteins. A third putative conserved region $\mathrm{C}$ underlined in Figure 2 was $[\mathrm{V} / \mathrm{M}][\mathrm{F} /$ $\mathrm{K}] \mathrm{P}[\mathrm{Q} / \mathrm{K} / \mathrm{I}] \mathrm{G}[\mathrm{L}][\mathrm{V} / \mathrm{I} / \mathrm{L}] \mathrm{HFQ}[\mathrm{K} / \mathrm{L} / \mathrm{Q} / \mathrm{I}] \mathrm{N}[\mathrm{V} / \mathrm{N} / \mathrm{I}] \mathrm{G}$. Two His residues and a Glu residue in Motif $\mathrm{A}$, together with a His residue in Motif $\mathrm{C}$, act as ligands for the binding of a manganese ion at the active site of the archetypal germin, cupin [42]. In our result, motif A was HTHPRATEILTVLEGTLYVGF with 21 amino acids, motif B was KVLNKGDVFVFPEGLIHFQFN with 21 amino acids, and motif $C$ was [N/S]SQNPGI VFVPLTLFG with 16 amino acids. The 21 GmGER genes all have the germin activity, exhibiting diverse expression patterns during soybean development, a regular photoperiodical reaction in darkness, response to abiotic stress (such as auxin and salt), as we have proved in this paper.

One question that remained to be answered was whether all germin or germin-like genes of soybean carried out the same functions and were regulated in the same way like in other species. Multi-sequence alignments of GLPs in barley and Arabidopsis, as well in other plant species showed some overlaps of multigene family structure, which would be helpful in functional annotation and the study of the evolutionary relationships among the genes [31]. Based on phylogenetic analysis, we concluded that the GmGER genes did not share a common expression pattern. Germin genes were functionally diverse but structurally related [43]. Large differences existed among several members of germin gene family. It was clear that soybean GmGER genes were homologous to the dicotyledon proteins in the phylogenetic tree (Figure 1). Sequence analyses revealed that GmGER 8, 9 and 10 were distinct from the other GmGER genes. The GmGER 8 and 9 were located on the same chromosome 7 , suggesting that they might be divergence from a common ancestor. Likewise, the GmGER 2, 3, 6, 11, 12, 13, 14 and 20 were closely related to each other. It was possible that they were recently descended from a common ancestor gene that evolved into different forms.

Germin and the GLP gene family could be divided into two distinct groups. The members in one group (germins) had relatively homogeneous sequences [44], meanwhile, the members in another group (GLPs) were much more numerous and showed high sequence divergence [45]. GLPs could be further divided into three subgroups based upon sequence conservation [37]. In this paper, the GmGER genes were also divided into three subgroups based upon sequence conservation. Systematic investigation of soybean germin gene family would be useful for defining origins of the germin and germin-like gene family. Although the functional significance of all these elements remained to be tested, a variety of regulatory mechanisms acting on the transcript abundance were found. The germin genes in rice have been confirmed to be expressed in all types of tissues and could be induced by biotic or abiotic stresses. Many of the stress-induced germin genes were physically colocalized with quantitative trait loci (QTL) for disease resistance, and the emerged evidence suggested that microRNAs might regulate their transcript abundances $[46,47]$. Oxalate oxidase could confer to enhance resistance to Sclerotinia blight in peanut [41]. In transformed sunflower, the expression of oxalate oxidase resulted in the induction of plant defense proteins [48]. In tissue sections derived from pea nodules, PsGER1 was shown to be the first known germin-like protein with superoxide dismutase activity [49].

A significant promotion of the expression of GmGER mRNA was achieved by quantitative real-time RT-PCR under the supplement of IAA in medium. As IAA is involved mainly in the regulation of cell elongation and stimulating cell division [50], this result suggested that GmGER genes might mediate the stimulating effect of auxin on cell division. It should be noticed that, although the GmGER gene responded to IAA, the affinity was unknown, which made it difficult to be certain that the GmGER gene was involved in auxin signaling, especially without additional physiologic evidence. Therefore, it should be investigated furthermore. 
Meanwhile, the assay of salt stress indicated that the transgenic seedlings of tobacco with GmGER 9 gene showed improved salt tolerance compared to the WT plants (Figure 7A, 7B, 7C, 7D, 7E and 7F), confirming that the GmGER 9 gene had a positive response to the salt condition. Salt stress could cause oxidative damage in plant, such as protein oxidation and lipid peroxidation [51]. Therefore, GmGER 9 gene remained a potential to improve the salt tolerance in transgenic plants.

Different families of genes have been reported to be associated with plant photoperiod including germin genes [19]. A significant difference was observed in the response to light/dark cycles by various genes and different species. The level of mRNA of Sinapis alba L. undergoes circadian oscillation during light/dark cycles with a maximum about $12 \mathrm{~h}$ after the light was turned on. This peak of mRNA accumulation occurred in light treatment [52]. By contrast, the level of GmGER mRNA reached its maximum about $12 \mathrm{~h}$ after light was turned off in this study. The peak of mRNA accumulation occurred during the dark period in darkness treatment and changed sharply. In the light treatment the mRNA had almost no expression. In the LD treatment, the mRNA level had mild change less than in SD treatment. The value of mRNA was a little higher in SD treatment than in LD treatment. These findings indicated that the transcription of the GmGER genes greatly depended on the duration of darkness.

\section{Conclutions}

In summary, 21 germin-like protein genes of soybean were identified and analyzed in this study. The results revealed that this novel family of germin-like proteins might represent an important mechanism in soybean to modulate diverse physiological and molecular processes. These findings provided the groundwork to assist functional studies of this novel GmGER family, and an opportunity to discover the roles of the germin family proteins, to underlie regulatory mechanisms during plant development and the responses to adverse environmental stimuli and to answer why several different genes were required to carry out these functions. Future studies using molecular, genetic, biochemical, physiological, and other approaches could provide insights into understanding the functions and elucidating the molecular mechanisms of soybean germin genes in plant defense responses and development.

\section{Methods}

\section{Sequence data and database search}

The nucleic acid sequences and EST sequences of germin and germin-like genes in Glycine max (L.) Merr. and in other species were searched from the GenBank database http://www.ncbi.nlm.nih.gov/Entrez/ with
BLASTP and TBLASTN program in NCBI with e-value 10 [53]. Then all the sequence data of germin and germin-like genes were downloaded (EST sequences for searching soybean cDNA and other nucleic acid sequences for analyzing the relationship among soybean germin genes). In an attempt to obtain all of the germin and germin-like genes in soybean, the EST sequences were used to search the soybean genomic DNA databases, Phytozome http://www.phytozome.net/soybean. php. The predicted protein sequences of putative soybean germin family members were also downloaded from these databases. The software Genescan web server http://genes.mit.edu/GENSCAN.html was used for gene prediction. Redundant hits were removed by manual inspection. The InterProScan program http://www.ebi. ac.uk/InterProScan/ was used to detect the germin and germin-like domains.

\section{Full-length cDNA sequences and chromosomal location of germin genes}

Here, a total of 123 soybean germin-like gene EST sequences were downloaded from the GenBank database. The coding regions of soybean candidates were used to perform a BLASTN search against all of the ESTs. If the hits showed a complete identity over the entire polypeptide, it was considered an entire and active gene in soybean. All the sequences that had been determined were used as query in BALSTN searches against the soybean genome data http://www.phytozome.net/soybean.php. The sequences of the 20 soybean linkage groups http://soybeanphysicalmap.org/[54] were also used as query in BALSTN searches against the soybean genome data http://www.phytozome.net/soybean. php. The two alignment results were used to calculate with Blastm.pl (edited by our laboratory), then arranged in Microsoft Office Excel 2003. The chart from these data was drawn by Mapchart http://www.kyazma.nl/ index.php/mc.JoinMap/. The genes were placed by the position on the genetic map and the physical map.

The 5' - and 3'-rapid amplification of cDNA ends (RACE) was performed to obtain the 5'- and 3' ends encoding the additional sequence of soybean germin genes. The SMART RACE cDNA Amplification Kit (Clontech) was used following the manufacturer's instructions. Samples of $1 \mu \mathrm{g}$ of total RNA from the leaves of soybean 'Maple arrow' were used for reverse transcription. The gene-specific primer GSP1 from the antisense strand was designed for 5'-RACE, and the gene-specific primer GSP2 from the sense strand was used for 3'-RACE. All RACE PCR reactions were performed using the following protocol: $94^{\circ} \mathrm{C}$ for $30 \mathrm{~s}, 70^{\circ} \mathrm{C}$ for $30 \mathrm{~s}$ and $72^{\circ} \mathrm{C}$ for $3 \mathrm{~min}$ for 5 cycles, followed by $94^{\circ}$ $\mathrm{C}$ for $30 \mathrm{~s}, 68^{\circ} \mathrm{C}$ for $30 \mathrm{~s}$ and $72^{\circ} \mathrm{C}$ for $3 \mathrm{~min}$ for 5 cycles, followed by $94^{\circ} \mathrm{C}$ for $30 \mathrm{~s}, 66^{\circ} \mathrm{C}$ for $30 \mathrm{~s}$ and $72^{\circ} \mathrm{C}$ 
for $3 \mathrm{~min}$ for 27 cycles. The PCR product was subcloned into pGEM-T vector and sequenced.

\section{Multiple sequence alignment and phylogenetic tree construction}

Multiple alignments of nucleic acid sequences were performed using ClustalW ([55]; http://www.ebi.ac.uk/clustalw/index.html) with the following parameters: gap opening penalty 10 , gap extension penalty 1.0 . The PAM series was used for the protein weight matrix. The results were represented with the help of the GeneDoc software [56]. Phylogenetic trees were constructed by the Neighbor Joining method using the MEGA3.0 program [57]. Each analysis was carried out at least twice.

\section{GmGER gene response to IAA stress}

In order to evaluate GmGER gene response to IAA in soybean development, 'Maple arrow' seedlings were surface sterilized and then placed on the soil under aseptic condition, and kept in growth chamber under white fluorescent light (600 umol m $\mathrm{m}^{-2} \mathrm{~s}^{-1}, 16 \mathrm{~h}$ light/8 h dark) at $25^{\circ} \mathrm{C}$ and $90 \%$ relative humidity. The seedlings without any treatment were used as the control. After germination for 7 days, the seedlings were transferred to plates supplemented with dosed IAA (100 uM) and grown for another 6 days. The seedlings were then sampled and frozen for further analysis.

\section{GmGER gene response to light/dark}

Seeds of soybean 'Maple arrow' were surface sterilized and then placed on the soil under aseptic condition and then kept in growth chamber under white fluorescent light (600 umol m $\mathrm{m}^{-2} \mathrm{~s}^{-1}, 16 \mathrm{~h}$ light $/ 8 \mathrm{~h}$ dark) at $25^{\circ} \mathrm{C}$ and $90 \%$ relative humidity. When the cotyledons had opened maximally, the seedlings were subjected to one of the four photoperiodic treatments: dark (continuous darkness up to $48 \mathrm{~h}$ ), light (continuous light up to $48 \mathrm{~h}$ ), SD (short-day, $8 \mathrm{~h}$ light and $16 \mathrm{~h}$ dark), LD (long-day, $16 \mathrm{~h}$ light and $8 \mathrm{~h}$ dark).

\section{Salt tolerance assay}

Seeds of transgenic tobacco with GmGER 9 gene were surface sterilized and then placed on MS medium [58] under aseptic condition and then kept in growth chamber under white fluorescent light $\left(600 \mathrm{umol} \mathrm{m}^{-2} \mathrm{~s}^{-1}, 16 \mathrm{~h}\right.$ light $/ 8 \mathrm{~h}$ dark) at $25^{\circ} \mathrm{C}$ and $90 \%$ relative humidity. In the same time, the WT tobacco seeds were also planted on MS medium as a control. After germination, seedlings of transgenic plants and WT plants with similar size were transferred to MS medium containing different concentrations of $\mathrm{NaCl}(0,150,250$ and $350 \mathrm{mM})$. After $30 \mathrm{~d}$, the fresh weights of 5 to 10 seedlings from each transgenic line and WT plants in each treatment were measured, and the stem lengths of tested seedlings were also measured and compared.

\section{Quantitative real-time RT-PCR}

Total RNA was isolated from the soybean leaves at 0,4 , $8,12,16,20,24,48$ hours after IAA treatment. The amplification of selected genes was performed by quantitative real-time RT-PCR with specific oligonucleotide primers: forward primer (TTCCTCTTTGCTCTTGTC) and reverse primer (AGTGTTTGTGGTGTTTCC), using the first strand $\mathrm{CDNA}$. DNase treatment was given for removing contaminating genomic DNA from RNA samples. The PCR reactions $(1 \times$ PCR buffer, $200 \mu \mathrm{m}$ dNTPs, $150 \mathrm{ng}$ of each gene specific primer, $5 \mathrm{U}$ Taq Polymerase and $1 \times$ SYBR-GreenR using Icycler (BioRad, USA) were carried out at $94^{\circ} \mathrm{C}$ for $1 \mathrm{~min}, 55^{\circ} \mathrm{C}$ for 1 min and $72^{\circ} \mathrm{C}$ for $1 \mathrm{~min}$ for 35 cycles. At the end of the PCR cycles, the products were analyzed through a melt curve analysis to check the specificity of the PCR amplification. Two replicates of each reaction were performed, and data were analyzed by Livak method [59] and expressed as normalized expression ratio $\left(2^{-\Delta \Delta C T}\right)$ of particular gene to specific stress treatment. Expression ratio was calculated as $\Delta \Delta \mathrm{C}_{\mathrm{T}}=\Delta \mathrm{C}_{\mathrm{T}}$ (gene) $-\Delta \mathrm{C}_{\mathrm{T}}$ $\left(\beta\right.$-tubulin); $\Delta \mathrm{C}_{\mathrm{T}}$ (gene) $=\Delta \mathrm{C}_{\mathrm{T}}$ (transgenic line $)-\Delta \mathrm{C}_{\mathrm{T}}$ (CK plant); $\Delta \mathrm{C}_{\mathrm{T}}(\beta$-tubulin $)=\Delta \mathrm{C}_{\mathrm{T}}$ (transgenic line $)$ $-\Delta C_{\mathrm{T}}$ (CK plant).

\section{Acknowledgements}

This study was conducted in the Key Laboratory of Soybean Biology of Chinese Education Ministry and Soybean Development Centre of Agricultural Ministry, financially supported by National High Technology Project (Contract No. 2006AA10Z1F1), National Core Soybean Genetic Engineering Project (Contract No. 2008ZX08004-002, 2009ZX08004-002B, 2009ZX08009-089B), Chinese National Natural Science Foundation (60932008, 30971810), National 973 Project (2009CB118400), Provincial Education Ministry for the team of soybean molecular design.

\section{Author details}

${ }^{1}$ Soybean Research Institute (Key Laboratory of Soybean Biology in Chinese Ministry of Education), Northeast Agricultural University, Harbin, PR China 150030. '2Department of Life Science, Northeast Agricultural University, Harbin, PR China 150030.

\section{Authors' contributions}

$M L$ performed the preliminary molecular experiments, interpreted the results and wrote the manuscript. YPH and JGG participated in the design. XJW conceived the study. WBL revised the manuscript. All authors read and approved the final manuscript.

Received: 17 January 2010 Accepted: 8 November 2010 Published: 8 November 2010

\section{References}

1. Lane BG: Cellular desiccation and hydration: developmentally regulated proteins, and the maturation and germination of seed embryos. FASEB Journal 1991, 5:2893-2901.

2. Bernier F, Lemieux G, Pallotta D: Gene families encode the major encystment-specific proteins of Physarum polycephalum plasmodia. Gene 1987, 59:265-277. 
3. Michalowski $C B$, Bohnert $H J$ : Nucleotide sequence of a rootspecific transcript encoding a germin-like protein from the halophyte Mesembryanthemum crystallinum. Plant Physiology 1992, 100:537-538.

4. Dumas B, Sailland A, Cheviet JP, Freyssinet G, Pallett K: Identification of barley oxalate oxidase as a germin-like protein. Comptes Rendus de I'Academie des Sciences Serie 3 Sciences de la Vie (France) 1993, 316:793-782.

5. Heintzen C, Fischer R, Melzer S, Kappeler S, Apel K, Staiger D: Circadian oscillations of a transcript encoding a germin like protein that is associated with cell walls in young leaves of the long-day plant. Sinapis alba L. Plant Physiology 1994, 106:905-915.

6. Hurkman WJ, Lane GB, Tanaka CK: Nucleotide sequence of a transcript encoding a germin-like protein that is present in salt-stressed barley (Hordeum vulgare L.) roots. Plant Physiology 1994, 104:803-804.

7. Domon JM, Dumas B, Lainé E, Meyer Y, David A, David H: Three glycosylated polypeptides secreted by several embryogenic cell cultures of pine show highly specific serological affinity to antibodies directed against the wheat germin apoprotein monomer. Plant Physiology 1995, 108:141-148.

8. Membré N, Berna A, Neutelings G, David A, David H, Staiger D, Vásquez Sáez J, Raynal M, Delseny M, Bernier F: cDNA sequence, genomic organization and differential expression of three Arabidopsis genes for germin/oxalate oxidase-like proteins. Plant Molecular Biology 1997, 35:459-469.

9. Dunwell JM, Gane PJ: Microbial relatives of seed storage proteins: conservation of motifs in a functionally diverse superfamilly of enzymes. Journal of Molecular Evolution 1998, 46:147-154.

10. Ono M, Sage-Ono K, Inoue M, Kamada H, Harada H: Transient increase in the level of mRNA for a germin-like protein in leaves of the short-day plant Pharbitis nil during the photoinduction of flowering. Plant and Cell Physiology 1996, 37:855-861.

11. Dunwell JM: Cupins: A new superfamilly of functionally diverse proteins that include germins and plant storage proteins. Biotechnology \& Genetic Engineering Reviews 1998, 15:1-32.

12. Shutov $A D$, Braun $H$, Chesnokov YV, Bäumlein $H$ : A gene encoding a vicilin-like protein is specifically expressed in fern spores. Evolutionary pathway of seed storage globulins. European Journal of Biochemistry 1998, 252:79-89.

13. Requena $L$, Bornemann $S$ : Barley (Hordeum vulgare) oxalate oxidase is a man-ganese-containing enzyme. Biochemical Journal 1999, 343:185-190.

14. Woo E, Dunwell J, Goodenough P, Marvier A, Pickersgill R: Germin is amanganese containing homohexamer with oxalate oxidase and superoxide dismutase activities. Nature Structural Biology 2000, 7:1036-1040.

15. Rodriguez LM, Baroja FE, Zandueta CA, Moreno BB, Munoz FJ, Akazawa T, Pozueta RJ: Two isoforms of a nucleotide-sugar pyrophosphatase/ phosphodiesterase from barley leaves (Hordeum vulgare L.) are distinct oligomers of HvGLP1, a germin-like protein. FEBS Letters 2001, 490:44-48.

16. Vallelian BL, Mosinger E, Metraux JP, Schweizer P: Structure, expression and localization of a germin-like protein in barley (Hordeum vulgare L.) that is insolubilized in stressed leaves. Plant Molecular Biology 1998, 37:297-308.

17. Schweizer $P$, Christoffel A, Dudler R: Transient expression of members of thegermin-like gene family in epidermal cells of wheat confers disease resistance. The Plant Journal 1999, 20:540-552.

18. Kim HJ, Pesacreta TC, Triplett BA: Cotton-fiber germin-like protein. II: Immu-nolocalization, purification, and functional analysis. Planta 2004, 218:525-535.

19. Mahmut Ç: Germin, an oxalate oxidase, has a function in many aspects of plant Life. Turkish Journal of Biology 2000, 24:717-724.

20. Berna $A$, Bernier F: Regulated expression of a wheat germin gene in tobacco: oxalate oxidase activity and apoplastic localization of the heterologous protein. Plant Molecular Biology 1997, 33:417-429.

21. Lane BG, Grzelczak Z, Kennedy T, Kajioka R, Orr J, D'Agostino S, Jaikaran A: Germin: compartmentation of the two forms of the protein by washing growing wheat embryos. Biochemistry and Cell Biology 1986, 64:1025-1037.

22. Lane BG, Dunwell JM, Ray JA, Schmitt MR, Cuming AC: Germin, a protein marker of early plant development, is an oxalate oxidase. Journal of Biological Chemistry 1993, 268:12239-12242.

23. Olson PD, Varner JE: Hydrogen peroxide and lignification. The Plant Journal 1993, 4:887-892.
24. Thordal-Christensen $\mathrm{H}$, Zhang $\mathrm{Z}$, Wei $\mathrm{Y}$, Collinge DB: Subcellular localization of $\mathrm{H}_{2} \mathrm{O}_{2}$ in plants. $\mathrm{H}_{2} \mathrm{O}_{2}$ accumulation in papillae and hypersensitive response during the barleypowdery mildew interaction. The Plant Journal 1997, 11:1187-1194.

25. Dunwell J, Gibbings JG, Mahmood T, Naqvi S: Germin and germin-like proteins: evolution, structure, and function. Critical Reviews in Plant Sciences 2008, 27:342-75.

26. Lane BG: Oxalate, germins, and higher-plant pathogens. IUBMB Life 2002, 53:67-75.

27. Dumas $B$, Freyssinet $G$, Pallett $K$ : Tissue-specific expression of germin-like OxO during development and fungal infection of barley seedlings. Plant Physiology 1995, 107:1091-1096.

28. Zhang Z, Collinge DB, Thordal-Christensen H: Germin-like, OxO, a $\mathrm{H}_{2} \mathrm{O}_{2}$ producing enzyme, accumulates in barley attacked by the powdery mildew fungus. The Plant Journal 1995, 8:139-145.

29. Wei Y, Zhang Z, Andersen C, Schmelzer E, Gregersen P, Collinge D, Smedegaard-Petersen $\mathrm{V}$, Thordal-Christensen $\mathrm{H}$ : An epidermis/papillaspecific oxalate oxidase-like protein in the defense response of barley attacked by the powdery mildew fungus. Plant Molecular Biology 1998, 36:101-112.

30. Lou Y, Baldwin I: Silencing of a germin-like gene in Nicotiana attenuata improves performance of native herbivores. Plant Physiology 2006, 140:1126-1136.

31. Zimmermann $G$, Baumlein $H$, Mock $H$, Himmelbach A, Schweizer P: The multigene family encoding germin-like proteins of barley: regulation and function in basal host resistance. Plant Physiology 2006, 142:181-192.

32. Godfrey D, Able A, Dry I: Induction of a grapevine germin-like protein (VvGLP3) gene is closely linked to the site of Erysiphe necator infection: a possible role in defense? Molecular Plant-Microbe Interactions 2007, 20:1112-1125

33. Hurkman WJ, Tanaka CK: Germin gene expression is induced in wheat leaves by powdery mildew infection. Plant Physiology 1996, 111:735-739.

34. Carrillo MGC, Goodwin PH, Leach FJE, Leung H, Cruz CMV: Phylogenomic relationships of rice oxalate oxidases to the cupin superfamily and their association with disease rsistance QTL. Rice 2009, 2:67-79.

35. Pauline AD, Terry A, Byron GL, Andren LD, Daina HS: Soybean plants expressing an active oligomeric oxalate oxidase from the wheat $\mathrm{gf}-2.8$ (germin)gene are resistant to the oxalate-secreting pathogen Sclerotina sclerotiorum. Physiological and Molecular Plant Pathology 2001, 59:297-307.

36. Carter C, Thornburg RW: Germin-like proteins: structure, phylogeny, and Function. Journal of Plant Biology 1999, 42(2):97-108.

37. Carter C, Thornburg RW: Tobacco nectarin I. Purification and characterization as a germin-like, manganese superoxide dismutase implicated in the defense of floral reproductive tissues. The journal of biologicalchemisty 2000, 275(47):36726-33.

38. Nakata M, Watanabe Y, Sakurai Y, Hashimoto Y, Matsuzaki M, Takahashi Y, Satoh T: Germin-like protein gene family of a moss, Physcomitrella patens, phylogenetically falls into two characteristic new clades. Plant Molecular Biology 2004, 56:381-395.

39. Ko TP, Ng JD, McPherson A: The three-dimensional structure of canavalin from Jack bean (Canavalia ensiformis). Plant Physiology 1993, 101:729-744.

40. Lawrence MC, Izard T, Beuchat M, Blagrove RJ, Colman PM: Structure of phaseolin at $2.2 \mathrm{~A}^{\circ}$ resolution; implications for a common vicilin/ legumin structure and the genetic engineering of seed storage proteins. Journal of Molecular Biology 1994, 238:748-776.

41. Livingsone DM, Hampton JL, Phipps PM, Grabau EA: Enhancing resistance to sclerotinia minor in peanut by expressing a barley oxalate oxidase gene. Plant Physiology 2005, 137:1354-1362.

42. Gane PJ, Dunwell JM, Warwicker J: Modeling based on the structure of vicilins predicts a histidine cluster in the active site of oxalate oxidase. Journal of Molecular Evolution 1998, 46:488-93.

43. Dunwell JM, Culham A, Carter CE, Sosa-Aguirre CR, Goodenough PW: Evolution of functional diversity in the cupin superfamily. Trends in Biochemical Sciences 2001, 26:740-6.

44. Lane BG: Oxalate oxidase and differentiating surface structure in wheat: germins. The Biochemical Journal 2000, 49:309-321.

45. Bernier F, Berna A: Germins and germin-like proteins: plant do-all proteins. But what do they do exactly? Plant Physiology and Biochemistry 2001, 39:545-554.

46. Rebecca MD, Patrick AR, Patricia MM, Jan EL: Germins: A diverse protein family important for crop improvement. Plant Sicence 2009, 177:499-510. 
47. Manosalva PM, Rebecca M, Davidson RM, Liu B, Zhu X, Hulbert SH, Leung $H$, Leach JE: A germin-like protein gene family functions as a complex quantitative trait locus conferring broad-spectrum disease resistance in rice. Plant Physiology 2009, 149:286-296.

48. Hu X, Bidney DL, Yalpani N, Duvick JP, Crasta O, Folkerts O, Lu G: Overexpression of a gene encoding hydrogen peroxide-generating oxalate oxidase evokes defense responses in sunflower. Plant Physiology 2003, 133:170-181.

49. Gucciardo S, Wisniewski JP, Brewin NJ, Bornemann S: A germin-like protein with superoxide dismutase activity in pea nodules with high protein sequence identity to a putative rhicadhesin receptor. Journal of Experimental Botany 2007, 58(5):1161-1171.

50. Campanoni P, Nick P: Auxin-dependent cell division and cell elongation 1-naphthaleneacetic acid and 2,4-dichlorophenoxyacetic. Plant Physiol 2005, 137:939-948

51. Davenport SB, Gallego SM, Benavides MP, Tomaro ML: Behaviour of antioxidant defense system in the adaptive response to salt stress in Helianthus annuus L. cells. Plant Growth Regul 2003, 40:81-8.

52. Heintzen C, Melzer S, Fischer R, Kappeler S, Apel K, Staiger D: A light- and temperature-entrained circadian clock controls expression of transcripts encoding nuclear proteins with homology to RNA-binding proteins in meristematic tissue. Plant Journal 1994, 6:799-813.

53. Altschul SF, Madden TL, Schaffer AA, Zhang J, Zhang Z, Miller W: Gapped BLAST and PSI-BLAST: A new generation of protein database search programs. Nucleic Acids Research 1997, 25:3389-402.

54. Choi IY, Hyten DL, Matukumalli LK, Song Q, Chaky JM, Quigley CV, Chase K, Lark KG, Reiter RS, Yoon MS, Hwang EY, Yi SI, Young ND, Shoemaker RC, van Tassell CP, Specht JE, Cregan PB: A Soybean Transcript Map: Gene Distribution, Haplotype and SNP Analysis. Genetics 2007, 176:685-696.

55. Thompson JD, Higgins DG, Gibson TJ: Clustal W: improving the sensitivity of progressive multiple sequence alignment through sequence weighting, position-specific gap penalties and weight matrix choice. Nucleic Acids Research 1994, 22:4673-80.

56. Nicholas KB, Nicholas HB Jr, Deerfield DW II: GeneDoc: analysis and visualization of genetic variation. EMBNEW News 1997, 4:13.

57. Kumar S, Tamura K, Nei M: MEGA3: integrated software for molecular evolutionary genetics analysis and sequence alignment. Brief Bioinform 2004, 5:150-63.

58. Murashige T, Skoog F: A revised medium for rapid growth and bioassays with tobacco cultures. Physiol Plant 1962, 159:473-9.

59. Michalik L, Auwerx J, Berger JP, Chatterjee VK, Glass CK, Gonzalez FJ, et al: International union of pharmacology. LXI. Peroxisome proliferatoractivated receptors. Pharmacological Reviews 2006, 58:726-41.

doi:10.1186/1471-2164-11-620

Cite this article as: Lu et al: Identification and analysis of the germin-

like gene family in soybean. BMC Genomics 2010 11:620.

\section{Submit your next manuscript to BioMed Central and take full advantage of:}

- Convenient online submission

- Thorough peer review

- No space constraints or color figure charges

- Immediate publication on acceptance

- Inclusion in PubMed, CAS, Scopus and Google Scholar

- Research which is freely available for redistribution

Submit your manuscript at www.biomedcentral.com/submit
Biomed Central 